\title{
Distribution of phosphorylated alpha-synuclein in non-diseased brain implicates olfactory bulb mitral cells in synucleinopathy pathogenesis
}

\author{
Bryan A. Killinger"a Gabriela Mercadob, Solji Choi ${ }^{a}$, Yaping Chuc, Patrik Brundin', and Jeffrey H. \\ Kordower ${ }^{C}$ \\ a Graduate College, Rush University Medical Center, Chicago Illinois 60612 \\ b Parkinson's Disease Center, Department of Neurodegenerative Science, Van Andel Institute, Grand Rapids MI 49503 \\ c ASU-Banner Neurodegenerative Disease Research Center (NDRC), Arizona State University, Tempe Arizona 85287
}

Synucleinopathies including Parkinson's disease and dementia with Lewy bodies are neurodegenerative diseases characterized by the intracellular accumulation of the protein alpha-synuclein called "Lewy pathology." Alpha-synuclein within Lewy pathology is aggregated into protease resistant filamentous structures and is predominantly phosphorylated at serine 129 (PSER129). Lewy pathology has been hypothesized to spread throughout the nervous system as the disease progresses. Cross-sectional studies have shown the olfactory bulb and olfactory tract consistently bare LP for common synucleinopathies, making these structures likely starting points for the spreading process, and thus disease. Here we examined the distribution of PSER129 in non-diseased brain. To do this we used a sensitive tyramide signal amplification (TSA) technique to detect low abundance endogenous PSER129 under ideal antibody binding conditions. In wild-type nondiseased mice, PSER129 was detected in the olfactory bulb and several brain regions of the olfactory cortex across the neuroaxis (i.e., olfactory bulb to brain stem). PSER129 was particularly apparent in the mitral cell layer and the outer plexiform layer of the olfactory bulb where it was observed as cytosolic/nuclear puncta or fibers, respectively. PSER129 immunoreactivity in the healthy olfactory bulb was abolished by pretreatment of the tissue with proteinase $K$, preabsorption of the primary antibody against the purified PSER129 peptide fragment, or the omission of the PSER129 antibody. Furthermore, PSER129 immunoreactivity was not observed in any brain region of alpha-synuclein knockout mice. Dual labeling for the PSER129 and the mitral cell marker TBX21 showed that PSER129 positive structures of the healthy OB were found in mitral cells. We found evidence of the same PSER129 positive structures in the olfactory bulb of nondiseased rats, non-human primates, healthy humans, but not individuals diagnosed with PD. Results suggest biological pathways responsible for alpha-synuclein phosphorylation are constitutively active in OB mitral cells and alpha-synuclein in these cells may be predisposed to pathological aggregation. Pathological seeds originating in mitral cells may act as a source for alpha-synuclein spread competent assemblies that spreads throughout the brain via fibers of the olfactory tract. Future studies should investigate the normal function of alpha-synuclein in the mitral cells of the olfactory bulb, which may give insight into synucleinopathy disease origins.

\section{Introduction}

Synucleinopathies are a group of neurodegenerative diseases characterized by intracellular aggregates of alphasynuclein called "Lewy pathology" (LP). LP are often observed in several characteristic distribution patterns in the diseased brain, which has led to the development of pathology staging schemes ${ }^{1,2}$. The brain structure that LP is most consistently found in is the $\mathrm{OB}$, where LP is often detected in both the diseased and occasionally in the non-diseased brain (i.e., incidental LP) ${ }^{2-4}$. It remains unclear why the OB commonly bares pathology in the human brain, but one possibility is this structure may be prone to pathology development, especially during normal aging ${ }^{5}$. Anosmia is a common prodromal symptom of PD/DLB ${ }^{6-9}$ strongly supporting the hypothesis that the neurodegenerative process begins in the olfactory bulb years prior to classical symptoms.

LP are complex molecularly heterogeneous intracellular structures containing protease resistant filaments made of misfolded alpha-synuclein predominantly phosphorylated at serine 129 (PSER129). Although alpha-synuclein is predominantly phosphorylated in LP, less than $4 \%$ of the total endogenous alpha-synuclein pool is phosphorylated 10. The enrichment of PSER129 for LP strongly suggests this post-translation modification (PTM) plays a role in the disease process, but this exact role remains unclear. Very little is understood about the cellular processes involved in PSER129 generation and the biological function of PSER129 in the brain. Investigations have primarily focused on whether PSER129 promotes or inhibits alphasynuclein accumulation as targeting the responsible kinases and/or phosphatases may be a viable therapeutic strategy. To date, PSER129 remains an agnostic proxy for the synucleinopathy disease process. The development of sensitive and specific antibodies to PSER129 has made the detection of LP routine, however the detection of endogenous PSER129 has been inconsistent possibly due to low levels of PSER129 making detection ambiguous and inconsistent ${ }^{11}$. For example previous attempts to identify endogenous PSER129 by immunohistochemistry have been impeded by high affinity off-target binding of commercially available antibodies that interferes with detection ${ }^{11}$.

Here we report and expand on an observation we made of PSER129 immunoreactivity in the olfactory bulb (OB) of healthy mammals. To do this we measured PSER129 across the neuroaxis of adult ( $>150$ DPN) wild-type and alpha-synuclein knockout mice using a sensitive tyramide signal amplification (TSA) procedure. We found PSER129 reactivity to be brain region specific with particularly high abundance in the mitral cell layer of the OB. The mitral cell layer of the olfactory bulb contained abundant PSER129 located in perinuclear punctate structures, also in the nuclear compartment, and in fibers projecting out the glomerulus were also heavily labeled. We confirmed these findings in 
bioRxiv preprint doi: https://doi.org/10.1101/2021.12.22.473905; this version posted January 12, 2022. The copyright holder for this preprint (which was not certified by peer review) is the author/funder, who has granted bioRxiv a license to display the preprint in perpetuity. It is made available under aCC-BY-NC-ND 4.0 International license.

\section{Distribution of Phosphorylated Alpha-synuclein}

the OB of non-synucleinopathy mice, rats, non-human primates, and in the human OB. In contrast, the OB of individuals with PD showed abundant PK resistant PSER129 positive inclusions (i.e., LP) but lacked the PK-sensitive PSER129 mitral cell immunoreactivity observed in the healthy OB. We conclude that alpha-synucleins in OB mitral cells might be predisposed to pathological aggregation.

\section{Results}

PSER129 Immunoreactivity in the Mouse Brain

PSER129 staining was regionally specific across the WT mouse brain (Figure 1A). PSER129 staining was most apparent in the olfactory bulb but also several other regions showed pronounced PSER129 staining including the accessory olfactory bulb, amygdala, nucleus accumbens, dentate gyrus, globus pallidus, hypothalamus, and substantia nigra reticulata (Figure 1B). Throughout the tissues PSER129 positive punctate structures could be seen in most A

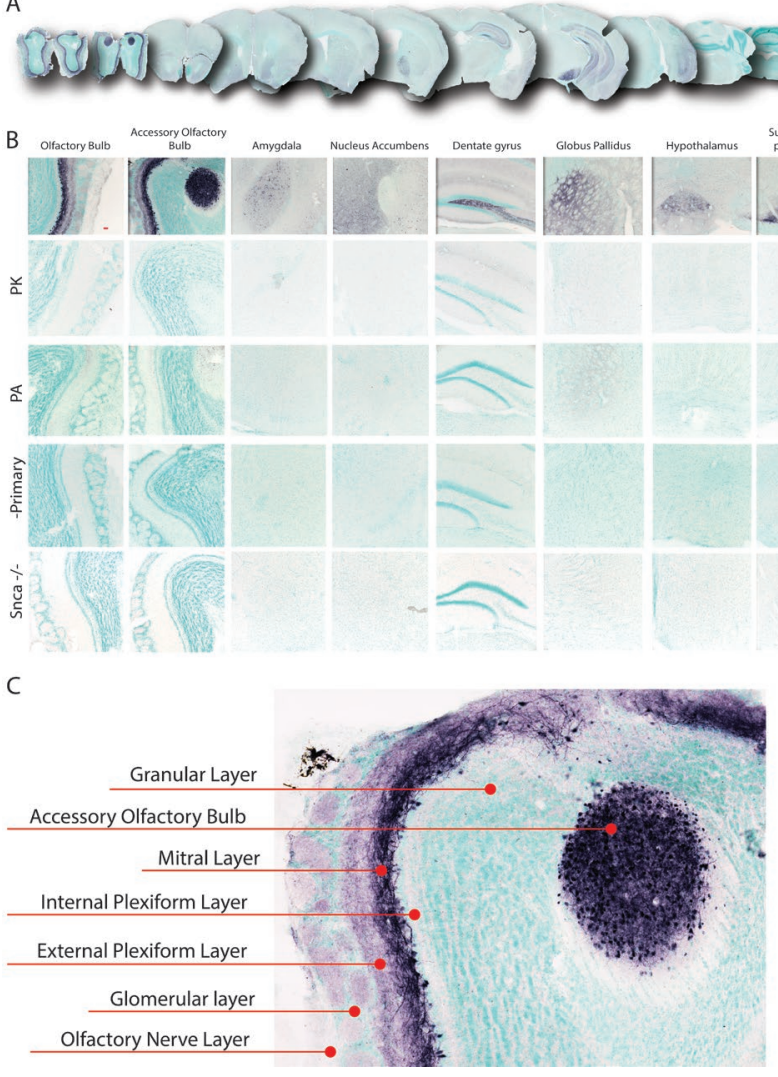

Figure 1: Distribution of PSER129 in the brain of non-diseased mice. (A) Representative images of coronal mouse brain sections stained for PSER129 using tyramide signal amplification. (B) Representative images of select brain regions with apparent PSER129 immunoreactivity at high magnification. Tissues digested with proteinase $\mathrm{K}$, (PK), incubated with anti-PSER129 antibody preabsorbed against PSER129 (PA), processed without primary antibody (-Primary) and from mice lacking alpha-synuclein (Snca-/-). Representative images of select brain regions are shown. Scale bars $=50$ microns. WTmice, $n=14$, Snca-/- mice, $n=7$. (C) Enlarged image from figure $B$, annotated to show the distribution of PSER129 across layers of the OB.

regions, except for the cerebellum. The brain stem and cerebellum lacked any discernable staining with the notable exception of a group of weakly PSER129 positive cells in the dorsal motor nucleus (not shown). Apparent nuclear staining was observed in many cortical regions including the amygdala. Intense fibers staining was observed in the nucleus accumbens, dentate gyrus, entorhinal cortex, global pallidus, and substantia nigra pars compacta (Figure 1B). PK digestion prior to immunostaining abolished PSER129 staining across the neuroaxis (Figure 1B, "PK"). Staining was weak when the primary antibody was pre-absorbed against the PSER129 peptide (Figure 1B, "PA"), which is consistent with competitive binding of pre-absorbed monoclonal antibodies (Figure S1,F,G) ${ }^{12}$. Staining was totally absent when the primary antibody was omitted from the staining protocol (Figure 1B "-Primary"). PSER129 reactivity appeared variable with some brains showing more prominent staining than others. In total we observed positive PSER129 staining in the OB of 13 out of 14 WT mice tested. In contrast, we did not observe PSER129 reactivity for the 7 alpha-synuclein knockout mice tested in any brain region under any IHC conditions (Figure 1B, Snca-/-).

In the olfactory bulb of WT mice, fibers and punctate structures were intensely labeled in the mitral cell layer, while fiber labeling was observed in the external plexiform layer (EPL) and glomeruli (GM) (See figure 1C for annotated reference). Intense labeling of apparent cells and fibers were observed in the accessory olfactory bulb (AOB). PSER129 labeling was nearly absent in the granular layer (GL), inner plexiform layer (IPL), and the olfactory nerve layer (ONL).

PSER129 Occurs as Punctate Structures in Mitral Cells

We wanted to determine the intracellular distribution of PSER129 in the olfactory bulb mitral layer. To do this we
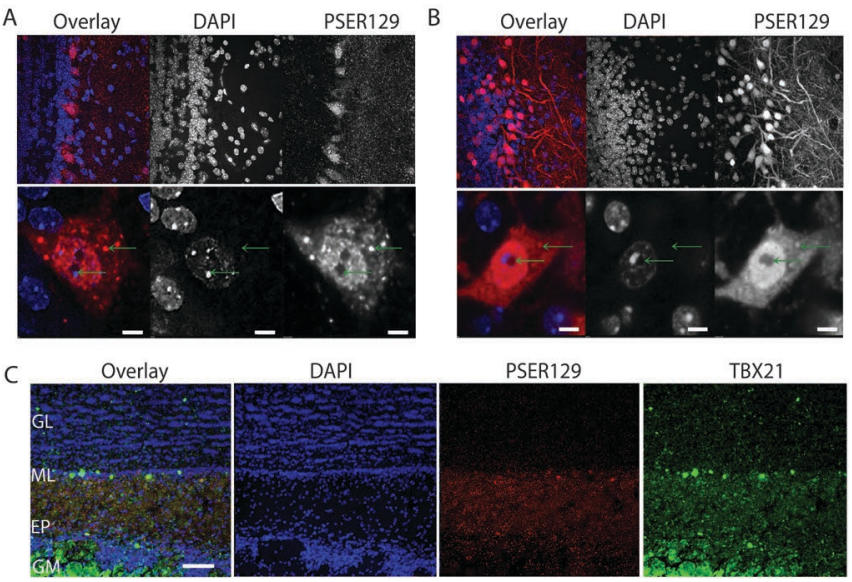

D

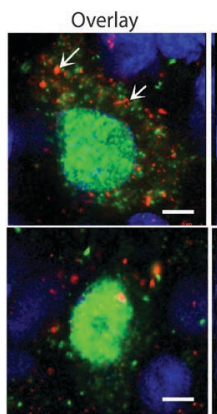

DAP

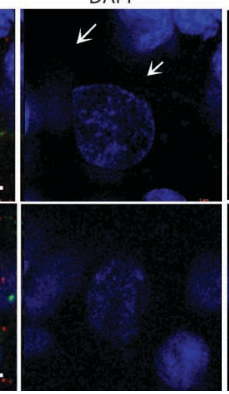

PSER129

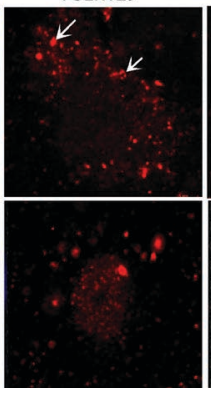

TBX 21

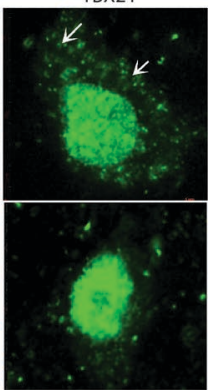

Figure 2: Localization and intracellular distribution of PSER129 in the non-diseased olfactory bulb. (A) PSER129 was fluorescently labeled using tyramide signal amplification in WT mice. Tissues were counterstained with DAPI. Representative images showing distribution of PSER129 in the OB.(B) Non-pathology bearing M83 mice labeled for PSER129. Non-human primate OB was dual labeled for PSER129 and mitral cell marker TBX21. (C) Low magnification confocal images showing regional distribution in non-human primate OB. (D) High magnification confocal images showing PSER129 puncta in TBX21 positive mitral cell. Green arrows denote intracellular punctate structures, both perinuclear and nuclear. WT mice $n=5$, M83 mice $n=2$, non-human primates $=2$, Scale bars for $A$ and $D=5$ microns. 
bioRxiv preprint doi: https://doi.org/10.1101/2021.12.22.473905; this version posted January 12,2022 . The copyright holder for this preprint (which was not certified by peer review) is the author/funder, who has granted bioRxiv a license to display the preprint in perpetuity. It is made available under aCC-BY-NC-ND 4.0 International license.

\section{Distribution of Phosphorylated Alpha-synuclein}

fluorescently labeled PSER129 in the OB of WT and M83 mice. Results confirmed PSER129 labeling in the mitral cell layer and diffuse punctate labeling in the outer plexiform layer of WT mice. Punctate labeling was observed throughout the plexiform layer. Cells within the mitral layer showed PSER129 granular staining in the nucleus and perinuclear compartments. Punctate PSER129 structures were observed both perinuclear and within the nucleus (Figure 2A and B, green arrows). PSER129 and DAPI weakly colocalized in these cells. M83 mice showed more prominent PSER129 labeling of the mitral cell layer and strong fibers labeling in the plexiform layer. Within the mitral layer cells showed strong nuclear and perinuclear PSER129 labeling. Some punctate structures could be observed in the nucleus and perinuclear, however, they were less pronounced that WT. Punctate PSER129 labeling in the outer plexiform layer extended to the glomerulus. PSER129 staining was not detected in the granular layer of any WT mice tested.

To determine if the punctate PSER129 staining originated in mitral cells we fluorescently labeled both PSER129 and the mitral cell marker TBX21 using the TSA protocol. This experiment was performed in the OB from

healthy non-human primates because the anti-TBX21 antibody used is of mouse origin, and therefore performing this experiment on mouse tissues using our IHC protocol produces ambiguous results. We had already observed the same PSER129 staining pattern in the non-human primate OB (see Figure 3) and therefore chose to asses PSER129 colocalization in this tissue. Results show TBX21 labeling was predominantly nuclear, in select cells of the mitral layer (Figure 2C). TBX21 labeling was observed in some perinuclear structures. Perinuclear PSER129 puncta were observed in TBX21 positive mitral cells. Within mitral cells PSER129 and TBX21 were not colocalize (Figure 2D).

\section{Mitral Cell PSER129 is Conserved Across Species}

Next, we wanted to determine if the same PSER129 positive mitral cells were conserved across species. To do this we stained for PSER129 in the olfactory healthy rats, non-human primates (2 years of age), healthy adults, and individuals diagnosed with PD (See Table S1 for Summary). Result showed mitral cell staining in rats, non-human primates, and humans, similar to what was observed in mice (Figure 3A). Antibody clone psyn\#64 also detected PSER129 in mitral cells (Figure S2). In the OB of human PD, we found that HIAR or PK digestion were required for PSER129 detection, but in the healthy OB HIAR was often required to observe PSER129 staining (Figure S3). PSER129 staining of the PD OB produces mostly fibers baring pathology, with a few cell bodies being immunoreactive. PSER129 positive inclusions could be detected across all layers of the $\mathrm{OB}$, however, staining in all cases tested was most prominent in the olfactory tract projecting out through the olfactory peduncle (Figure 3B). We attempted to verify that $\mathrm{OB}$ mitrals cells were intact in all samples tested using the TBX21 antibody (Figure S4), however, we found immunoreactivity was absent from several human samples (See table S1) which has been reported previously 13 and may result from differences in post-mortem interval.

\section{Discussion}

Mitral cells in synucleinopathies

The OB been hypothesized to be a starting point for alpha-synuclein pathology and therefore the synucleinopathy disease process. This contention is supported by several observations including 1) mitral cell loss in $\mathrm{PD} O \mathrm{OB} 2,5,13,14,2$ ) high-incidence of mitral cell LP in synucleinopathy $\mathrm{OB}^{3,5,15,16} 3$ ) and incidental LP in $\mathrm{OB}^{3}$. Our inadvertent observation of disease associated PSER129 in healthy mitral cells seems to support this hypothesis. However, it is unlikely that all mammalian mitral cells harbor disease causing aggregates, but instead the phosphorylation of alpha-synuclein likely has some unknown biological significance in mitral cells. Currently we can only speculate as to what biological process is responsible for PSER129 in mitral cells. However, because mitral cells eventually develop LP in the disease brain, it is important to understand the biological process generating PSER129 in mitral cells, and if those processes are involved with the alpha-synuclein aggregation process, and thus disease pathogenesis. Factor such as normal aging are likely to have particular significance for mitral cell pathology 5 .

Mitral and tufted cells are primarily glutamatergic neurons of the olfactory bulb, and these cells both seem susceptible to the synucleinopathy disease process while dopaminergic cells of the OB seem resistant ${ }^{15}$. Alphasynuclein oligomers can induce calcium dependent

A
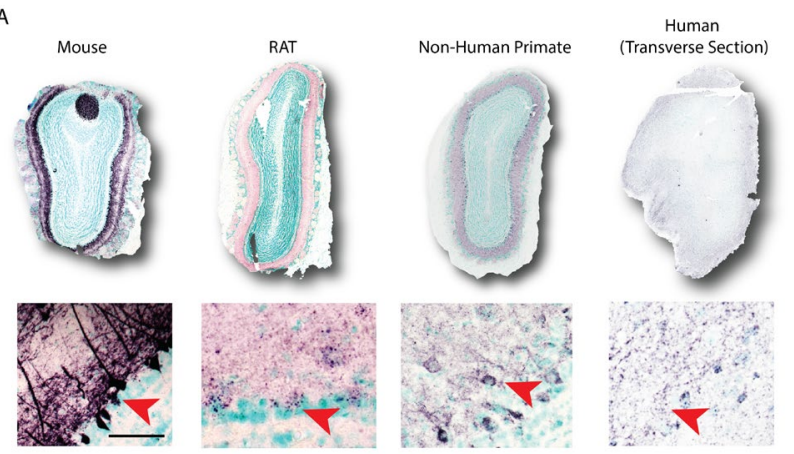

B

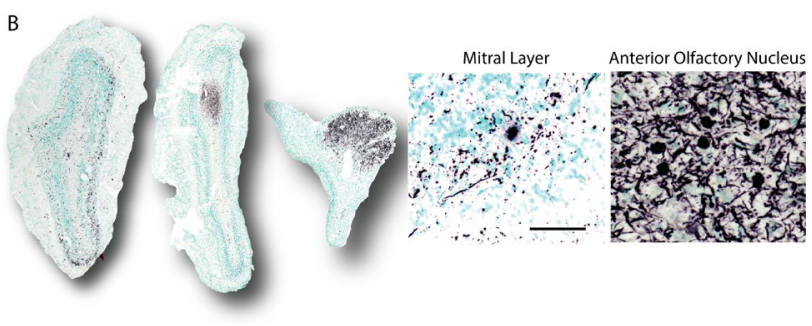

Figure 3: Mitral cell PSER129 is conserved across species (A) Representative images of PSER129 staining in OB sections from mice, rat, non-human primate, and human. All sections were coronal, except for human $\mathrm{OB}$ which was section in the transverse plane. Depicted below each olfactory bulb are high magnification images of staining in the mitral layer. Scale bar $=50$ microns. $(B)$ Representative images of PSER129 staining in PD/DLB OB. Sections from the main bulb are depicted as well as the peduncle. High magnification images show PSER129 staining in the mitral layer and anterior olfactory nucleus. Scale bar $=50$ microns.

glutamate release from astrocytes ${ }^{17}$ and can activate extrasynaptic NMDA receports (eNMDAR) resulting in cytotoxicity ${ }^{17}$. NMDA receptors are expressed in mitral cells 
bioRxiv preprint doi: https://doi.org/10.1101/2021.12.22.473905; this version posted January 12,2022 . The copyright holder for this preprint (which was not certified by peer review) is the author/funder, who has granted bioRxiv a license to display the preprint in perpetuity. It is made available under aCC-BY-NC-ND 4.0 International license.

Distribution of Phosphorylated Alpha-synuclein

and participate in normal mitral cell function/activity 18,19 . Mitral cell glutamate release is calcium dependent and selfexcitatory via NMDAR's. There is some evidence that glutamate stimulation can increase polo-like kinase 2 expression and PSER129 abundance ${ }^{20}$. Together, alphasynuclein's involvement mitral cell glutamate signalling may be related to the observed PSER129 abundance. PSER129 immunoreactivity was most pronounced in mice and monkeys that had been anesthetized with Ketamine (an NMDAR antagonist) prior to perfusion fixation, and less pronounced in rats and humans, who were not exposed to ketamine prior to death. Therefore, it is possible that ketamines effect on glutamate signialling results in PSER129 production in mitral cells. However, one WT mouse exposed to ketamine showed very little PSER129 immunoreactivity in the OB.

Mitral and tufted cells have a apical dendrite that extends to a single glomulerous but they also extend several axons into telencephalon regions including the amygdala ${ }^{21}$. These axons extend out through the olfactory tract. We observed occasional LP in the mitral cell layer of DLB and PD OB, but consistently saw dense lewy neurites (LN) throughout the anterior olfcatory nuclei of the main bulb and peduncle. Brain regions known to be suseptible to LP were PSER129 immunoreactive in WT mice. If PSER129 containing brain regions are normally suseptible to pathology formation ${ }^{22}$, then our observations corroborates a hypothesis that olfactory cortex projections are the primary pathogenic origin of synucleinopathies ${ }^{14,15,23-26}$.

Studies herein where initiated because we had observed regionally specific anomalous PSER129 signal in untreated healthy wildtype mice. Interestingly others have observed this mitral cell staining phenomenon but not realized the significance ${ }^{27}$. We demonstrated that the anomalous PSER129 signal was likely an endogenous PSER129 population sensitive to PK digestion that occurred in the mitral cells of healthy mammals. In mitral cells both diffuse and punctate structures were intensely labeled in the nucleus, cytoplasm, and often observed throughout their apical dendrite. The apparent pattern of PSER129 staining was seen in mice, rats, non-human primates, and a neurologically intact human. This suggest the role of PSER129 in OB mitral cells is conserved across mammalian species. However, mitral cell PSER129 reactivity was not universal, as we did not observe any staining in 1 mouse and 3 healthy humans. This suggests that either PSER129 is generated in mitral cells driven by undetermined fluctuating cellular process or the PSER129 epitope is not accessible in some tissues. We explore many epitope retrieval methods, and found that heat mediate epitope retrieval could enhance reactivity, but did not unmask reactivity in samples that showed no PSER129 reactivity. In mice, we observed an "all-or-none" phenomenon where samples with little/no OB staining also had little/no staining in other brain regions. The reason for this phenomenon is still not clear.

In agreement with previous reports, results from our studies show that improper dilution of EP1536Y results in abundant off target binding as determined by IHC and blotting techniques (Figure S1,B). In contrast to previous reports, we demonstrate that endogenous PSER129 is detectable provided EP1536Y is highly dilute and the secondary detection system is sufficiently sensitive (in this case TSA). In our hands we found much higher dilutions of EP1536Y than commonly used (Abcam) are necessary to ensure on target binding, and commonly employed dilutions have a high probability of generating false positive detection. In our hands, EP1536Y could be diluted to $\sim 3 \mathrm{pg}$ / $\mathrm{mL}\left(1: 1 \mathrm{X} 0^{9}\right.$ dilution) and still show on target staining. This gives a large window of effective concentrations for this antibody, as we also observed that non-specific binding is eliminated somewhere between $1: 10 \mathrm{~K}$ and $1: 20 \mathrm{~K}$ dilutions (Fig S1, B).

Synucleinopathy has not been observed as a function of aging in mammals besides humans for unknown reasons. Lesions resembling human tau tangles and amyloid plaques have been observed in mammals other than humans ${ }^{28}$ but its not clear why LP is not seen in other mammals. The human $\mathrm{OB}$ is unique amongst mammals in several aspects including that it only has limited post-natal neurogenesis ${ }^{28}$. Human samples had the least prominent PSER129 staining of all species tested (Figure 3A). One possibility is that PSER129 represents a protective mechanism that prevents pathological aggregation ${ }^{29}$ and perhaps human mitral cells are particularly deficient in this neuroprotective phosphorylation event as they age.

\section{Study Limitations}

Studies herein are based on antibody affinity, and although we have included several controls (i.e., alphasynuclein knockout mice, antibody preabsorbtion, and primary antibody negative conditions) we cannot rule out the possibility of immune mimicry ${ }^{12}$. However, our finding that under several IHC protocols tested (e.g., HIAR, PK), we did not observe any PSER129 immunoreactivity in any brain structure of seven alpha-synuclein knockout mice. In contrast, nearly all (14/15) of the WT mice tested had readily apparent immunoreactivity in the $\mathrm{OB}$ mitral layer.

\section{Conclusion}

OB mitral cells harbor the disease associated alphasynuclein PTM PSER129 and have previously implicated in disease pathogenesis. We conclude that determining the cellular and molecular processes that regulate PSER129 in OB mitral cells might provide important insights into the origins of synucleinopathies.

\section{References}

1 Braak, H. et al. Staging of brain pathology related to sporadic Parkinson's disease. Neurobiol Aging 24, 197-211, doi:10.1016/s01974580(02)00065-9 (2003).

2 Beach, T. G. et al. Unified staging system for Lewy body disorders: correlation with nigrostriatal degeneration, cognitive impairment and motor dysfunction. Acta Neuropathol 117, 613-634, doi:10.1007/s00401-009-0538-8 (2009).

3 Beach, T. G. et al. Multi-organ distribution of phosphorylated alphasynuclein histopathology in subjects with Lewy body disorders. Acta Neuropathol 119, 689-702, doi:10.1007/s00401-010-0664-3 (2010).

4 Beach, T. G. et al. Olfactory bulb alpha-synucleinopathy has high specificity and sensitivity for Lewy body disorders. Acta Neuropathol 117, 169-174, doi:10.1007/s00401-008-0450-7 (2009).

5 Sengoku, R. et al. Incidence and extent of Lewy body-related alphasynucleinopathy in aging human olfactory bulb. J Neuropathol Exp Neurol 67, 1072-1083, doi:10.1097/NEN.0b013e31818b4126 (2008).

6 Olichney, J. M. et al. Anosmia is very common in the Lewy body variant of Alzheimer's disease. J Neurol Neurosurg Psychiatry 76, 1342-1347, doi:10.1136/jnnp.2003.032003 (2005). 
bioRxiv preprint doi: https://doi.org/10.1101/2021.12.22.473905; this version posted January 12, 2022. The copyright holder for this preprint (which was not certified by peer review) is the author/funder, who has granted bioRxiv a license to display the preprint in perpetuity. It is made available under aCC-BY-NC-ND 4.0 International license.

\section{Distribution of Phosphorylated Alpha-synuclein}

7 Ross, G. W. et al. Association of olfactory dysfunction with risk for future Parkinson's disease. Ann Neurol 63, 167-173, doi:10.1002/ana.21291 (2008).

8 Chiba, Y. et al. Retrospective survey of prodromal symptoms in dementia with Lewy bodies: comparison with Alzheimer's disease. Dement Geriatr Cogn Disord 33, 273-281, doi:10.1159/000339363 (2012)

9 Fujishiro, H. et al. Dementia with Lewy bodies: early diagnostic challenges. Psychogeriatrics 13, 128-138, doi:10.1111/psyg.12005 (2013).

10 Fujiwara, H. et al. alpha-Synuclein is phosphorylated in synucleinopathy lesions. Nat Cell Biol 4, 160-164, doi:10.1038/ncb748 (2002).

11 Delic, V. et al. Sensitivity and specificity of phospho-Ser129 alphasynuclein monoclonal antibodies. J Comp Neurol 526, 1978-1990, doi:10.1002/cne.24468 (2018).

12 Ivell, R., Teerds, K. \& Hoffman, G. E. Proper application of antibodies for immunohistochemical detection: antibody crimes and how to prevent them. Endocrinology 155, 676-687, doi:10.1210/en.2013-1971 (2014)

13 Cave, J. W., Fujiwara, N., Weibman, A. R. \& Baker, H. Cytoarchitectural changes in the olfactory bulb of Parkinson's disease patients. NPJ Parkinsons Dis 2, 16011, doi:10.1038/npjparkd.2016.11 (2016).

14 Daniel, S. E. \& Hawkes, C. H. Preliminary diagnosis of Parkinson's disease by olfactory bulb pathology. Lancet 340,186, doi:10.1016/01406736(92)93275-r (1992).

15 Ubeda-Banon, I. et al. alpha-Synucleinopathy in the human olfactory system in Parkinson's disease: involvement of calcium-binding protein- and substance P-positive cells. Acta Neuropathol 119, 723-735, doi:10.1007/s00401-010-0687-9 (2010).

16 Kovacs, T., Papp, M. I., Cairns, N. J., Khan, M. N. \& Lantos, P. L. Olfactory bulb in multiple system atrophy. Mov Disord 18, 938-942, doi:10.1002/mds.10466 (2003)

17 Trudler, D. et al. alpha-Synuclein Oligomers Induce Glutamate Release from Astrocytes and Excessive Extrasynaptic NMDAR Activity in Neurons, Thus Contributing to Synapse Loss. J Neurosci 41, 2264-2273, doi:10.1523/JNEUROSCI.1871-20.2020 (2021).

18 Philpot, B. D., Lyders, E. M. \& Brunjes, P. C. The NMDA receptor participates in respiration-related mitral cell synchrony. Exp Brain Res 118, 205-209, doi:10.1007/s002210050273 (1998).

19 Ennis, M., Zimmer, L. A. \& Shipley, M. T. Olfactory nerve stimulation activates rat mitral cells via NMDA and non-NMDA receptors in vitro. Neuroreport 7, 989-992, doi:10.1097/00001756-199604100-00007 (1996).

20 Tan, Y. et al. LY354740 Reduces Extracellular Glutamate Concentration, Inhibits Phosphorylation of Fyn/NMDARs, and Expression of PLK2/pS129 alpha-Synuclein in Mice Treated With Acute or SubAcute MPTP. Front Pharmacol 11, 183, doi:10.3389/fphar.2020.00183 (2020).

21 Scott, J. W., McBride, R. L. \& Schneider, S. P. The organization of projections from the olfactory bulb to the piriform cortex and olfactory tubercle in the rat. J Comp Neurol 194, 519-534, doi:10.1002/cne.901940304 (1980).

22 Zhou, J. et al. Changes in the solubility and phosphorylation of alphasynuclein over the course of Parkinson's disease. Acta Neuropathol 121, 695-704, doi:10.1007/s00401-011-0815-1 (2011).

23 Del Tredici, K., Rub, U., De Vos, R. A., Bohl, J. R. \& Braak, H. Where does parkinson disease pathology begin in the brain? J Neuropathol Exp Neurol 61, 413-426, doi:10.1093/jnen/61.5.413 (2002).

24 Hoogland, P. V., van den Berg, R. \& Huisman, E. Misrouted olfactory fibres and ectopic olfactory glomeruli in normal humans and in Parkinson and Alzheimer patients. Neuropathol Appl Neurobiol 29, 303311, doi:10.1046/j.1365-2990.2003.00459.x (2003).

25 Hubbard, P. S., Esiri, M. M., Reading, M., McShane, R. \& Nagy, Z. Alphasynuclein pathology in the olfactory pathways of dementia patients. Anat 211,117-124, doi:10.1111/j.1469-7580.2007.00748.x (2007).

26 Ubeda-Banon, I., Flores-Cuadrado, A., Saiz-Sanchez, D. \& MartinezMarcos, A. Differential Effects of Parkinson's Disease on Interneuron Subtypes within the Human Anterior Olfactory Nucleus. Front Neuroanat 11,113, doi:10.3389/fnana.2017.00113 (2017).

27 Niu, H. et al. IL-1beta/IL-1R1 signaling induced by intranasal lipopolysaccharide infusion regulates alpha-Synuclein pathology in the olfactory bulb, substantia nigra and striatum. Brain Pathol 30, 11021118, doi:10.1111/bpa.12886 (2020).

28 Arnsten, A. F. T. et al. Alzheimer's-like pathology in aging rhesus macaques: Unique opportunity to study the etiology and treatment of
Alzheimer's disease. Proc Natl Acad Sci U S A doi:10.1073/pnas.1903671116 (2019).

29 Arawaka, S., Sato, H., Sasaki, A., Koyama, S. \& Kato, T. Mechanisms underlying extensive Ser129-phosphorylation in alpha-synuclein aggregates. Acta Neuropathol Commun 5, 48, doi:10.1186/s40478-0170452-6 (2017)

\section{Acknowledgements}

Human brain samples were generously provided by several tissue banks including the Rush Movement Disorders Brain Bank, the Alzheimer's Brain Bank, and BH Banner Health Research. Funding for this work was provided by NIDCD Award \#R01DC06519 (PB and GM) and NINDS Award \#5R21NS109871-02 (JHK,).

\section{Competing interest statement}

We have no competing interests to declare.

\section{Materials and Methods \\ Biological Specimens}

All rodent and non-human primate tissues were derived from studies conducted in accordance with institutional IACUC approved protocols. All animals were anesthetized (ketamine/xylazine for rodents, and ketamine/xylaxine/hydromorphone for non-human primates) transcranial perfused with PBS pH 7.4 followed by $4 \%$ paraformaldehyde in PBS $\mathrm{pH}$ 7.4. Collected brain tissues were then post fixed in $4 \%$ paraformaldehyde overnight at $4^{\circ} \mathrm{C}$, dehydrated in successive sucrose solutions in PBS (i.e., $10 \%, 20 \%$, and $30 \%$ sucrose, $\mathrm{w} / \mathrm{v}$ ), and cut to 40 -micron coronal sections on a freezing stage microtome. Human olfactory bulbs from individual diagnosed with PD were supplied by the Rush Movement Disorders Brain Bank. OB specimens from individuals without synucleinopathy (HC) were provided by Rush Alzheimer's Brain Bank and BH Banner Health Research. Human and non-human primate OBs were sectioned following embedding in OCT compound (ThermoFisher). One human non-synucleinopathy case was obtained from banner health embedded in paraffin wax.

\section{Immunohistochemistry}

Free floating paraformaldehyde fixed mouse sections gathered at intervals of 940 microns across the neuroaxis (i.e. OB to brainstem) were first incubated in peroxidase quenching solution $(0.3 \%$ hydrogen peroxide, $0.1 \%$ sodium azide) in TBST ( $50 \mathrm{mM}$ Tris- $\mathrm{HCl} \mathrm{pH} 7.6,150 \mathrm{mM} \mathrm{NaCl}$, and $0.5 \%$ Triton $\mathrm{X}-100$ ) for $30 \mathrm{~min}$ at room temperature. Sections were then rinsed twice with PBS, and incubated with blocking buffer (3\% goat serum, $2 \%$ BSA, TBST) for $1 \mathrm{~h}$ at room temperature. Sections were then incubated with either anti-PSER129 (Abcam) diluted 1:50,000 or TBX21 antibody (Santacruz) diluted 1:10,000 in blocking buffer overnight at $4^{\circ} \mathrm{C}$. The next day sections were washed twice with TBST and incubated with biotinylated anti-rabbit or anti-mouse antibodies (Vectorlabs) diluted 1:400 in blocking buffer for $1 \mathrm{~h}$ at room temperature. Sections were then wash 3 times for ten minutes each in TBST and then incubated with prepared elite $\mathrm{ABC}$ reagent (Vector Labs) for $1 \mathrm{~h}$ at room temperature. Sections were then washed 2 times for $10 \mathrm{~min}$ in TBST and then washed 2 times for $10 \mathrm{~min}$ in sodium borate buffer (0.05M Sodium Borate, $\mathrm{pH}$ 8.5). Sections were then incubated $30 \mathrm{~min}$ with amplification buffer consisting of $1 \mu \mathrm{g} / \mathrm{mL}$ biotinyin tyramide (Thermofisher) and $0.003 \%$ hydrogen peroxide diluted in sodium borate buffer. Then sections were washed 3 times for $10 \mathrm{~min}$ in TBST and incubated again in the previously prepared elite ABC reagent for $1 \mathrm{~h}$ at room temperature. Sections were then washed 3 times for $10 \mathrm{~min}$ in TBST. Sections were then developed for exactly 2 min using a standard nickel enhanced DAB-imidazole protocol. Mounted sections were counterstained with methylgreen, dehydrated with ethanol, cleared with xylenes, and coversliped with cytoseal 60 .

For some experiments sections were digested with proteinase $\mathrm{K}$ prior to IHC. These sections were first mounted onto gelatin coated slides, dried, and baked overnight at $55^{\circ} \mathrm{C}$. Slides were then placed into PBS for 10 min and then proteinase $\mathrm{K}$ digestion buffer (TBS, $0.1 \%$ triton X100, $20 \mu \mathrm{g}$ proteinase $\mathrm{K} / \mathrm{mL}$, warmed to $37^{\circ} \mathrm{C}$ ) for $20 \mathrm{~min}$. Sections were rinsed with PBS, incubated with $4 \%$ paraformaldehyde for $10 \mathrm{~min}$, and rinsed off twice with TBST. Digested sections were then processed as stated above. For some experiments heat induced antigen retrieval (HIAR) was performed prior to staining. To perform HIAR citrate buffer $(10 \mathrm{mM}$ sodium citrate, $0.05 \%$ Tween 20 , pH 6.0) was heated in a water bath to $95^{\circ} \mathrm{C}$, slides then immersed in this solution for $30 \mathrm{~min}$, and then allowed to cool to room temperature.

For fluorescent detection, CF-546 or CF-647 tyramide conjugates (Biotium) were substituted for biotinyl tyramide at a final 
bioRxiv preprint doi: https://doi.org/10.1101/2021.12.22.473905; this version posted January 12, 2022. The copyright holder for this preprint (which was not certified by peer review) is the author/funder, who has granted bioRxiv a license to display the preprint in perpetuity. It is made available under aCC-BY-NC-ND 4.0 International license.

\section{Distribution of Phosphorylated Alpha-synuclein}

concentration of $1 \mu \mathrm{g} / \mathrm{mL}$. Incubation with fluorescent tyramides was restricted to $20 \mathrm{~min}$ to avoid saturated fluorescent labeling. Fluorescently labeled sections were mounted onto gelatin coated slides, dried for $20 \mathrm{~min}$, and mounted with \#1 glass coverslip using FluoroShield (Sigma-Aldrich).

For some experiments paraffin embedded sections were used. Prior to IHC these sections were heated in an oven to $60^{\circ} \mathrm{C}$, cleared with xylenes, and rehydrated with successive ethanol solutions from $100 \%$ to $50 \%$. Once hydrated sections were processed according to immunostaining protocols.

\section{Microscopy}

All samples were imaged on an inverted confocal microscope (Nikon A1R) Whole slide bright-field images using a $4 \mathrm{X}$ or $10 \mathrm{X}$ objective were acquired for DAB labeled sections. Confocal images were acquired for fluorescently labeled sections using a $60 \mathrm{X}$ oil immersion objective. Confocal images were deconvoluted using Nikon elements software. 
bioRxiv preprint doi: https://doi.org/10.1101/2021.12.22.473905; this version posted January 12,2022 . The copyright holder for this preprint (which was not certified by peer review) is the author/funder, who has granted bioRxiv a license to display the preprint in perpetuity. It is made available under aCC-BY-NC-ND 4.0 International license.

Distribution of Phosphorylated Alpha-synuclein

Table S1: List of Specimens and Summary of Results.

\begin{tabular}{|c|c|c|c|c|c|c|c|c|c|}
\hline$\#$ & Species & Sex & $\begin{array}{c}\text { Age at } \\
\text { death } \\
\text { (yrs) }\end{array}$ & $\begin{array}{l}\text { Method of } \\
\text { fixation }\end{array}$ & Strain & $\begin{array}{l}\text { Gen- } \\
\text { otype }\end{array}$ & $\begin{array}{l}\text { EP1536Y } \\
\text { staining* }\end{array}$ & $\begin{array}{c}\text { TBX21 } \\
\text { staining } \dagger\end{array}$ & Disease \\
\hline 1 & $\begin{array}{c}\text { Mus muscu- } \\
\text { lus }\end{array}$ & $\mathrm{M}$ & 0.66 & $\mathrm{PF} / \mathrm{DF}$ & $\mathrm{C} 57 \mathrm{BL} / 6 \mathrm{~J}$ & $\begin{array}{c}\alpha \text {-syn } \\
\text { KO }\end{array}$ & 0 & 1 & NA \\
\hline 2 & $\begin{array}{c}\text { Mus muscu- } \\
\text { lus }\end{array}$ & $\mathrm{M}$ & 0.66 & $\mathrm{PF} / \mathrm{DF}$ & C57BL/6J & $\begin{array}{c}\alpha \text {-syn } \\
\text { KO }\end{array}$ & 0 & 1 & NA \\
\hline 3 & $\begin{array}{c}\text { Mus muscu- } \\
\text { lus }\end{array}$ & $\mathrm{M}$ & 0.66 & $\mathrm{PF} / \mathrm{DF}$ & C57BL/6J & $\begin{array}{c}\alpha \text {-syn } \\
\text { KO }\end{array}$ & 0 & 1 & NA \\
\hline 4 & $\begin{array}{c}\text { Mus muscu- } \\
\text { lus }\end{array}$ & $\mathrm{M}$ & 0.66 & $\mathrm{PF} / \mathrm{DF}$ & C57BL/6J & $\begin{array}{c}\alpha \text {-syn } \\
\text { KO }\end{array}$ & 0 & 1 & NA \\
\hline 5 & $\begin{array}{c}\text { Mus muscu- } \\
\text { lus }\end{array}$ & M & 0.66 & $\mathrm{PF} / \mathrm{DF}$ & C57BL/6J & WT & 1 & 1 & NA \\
\hline 6 & $\begin{array}{c}\text { Mus muscu- } \\
\text { lus }\end{array}$ & $\mathrm{M}$ & 0.66 & $\mathrm{PF} / \mathrm{DF}$ & C57BL/6J & WT & 1 & 1 & NA \\
\hline 7 & $\begin{array}{c}\text { Mus muscu- } \\
\text { lus }\end{array}$ & $\mathrm{M}$ & 0.66 & $\mathrm{PF} / \mathrm{DF}$ & C57BL/6J & WT & 0 & 1 & NA \\
\hline 8 & $\begin{array}{c}\text { Mus muscu- } \\
\text { lus }\end{array}$ & $\mathrm{M}$ & 0.66 & $\mathrm{PF} / \mathrm{DF}$ & C57BL/6J & WT & 1 & 1 & NA \\
\hline 9 & $\begin{array}{c}\text { Mus muscu- } \\
\text { lus }\end{array}$ & $\mathrm{M}$ & 0.83 & $\mathrm{PF} / \mathrm{DF}$ & C57BL/6J & WT & 1 & ND & NA \\
\hline 10 & $\begin{array}{c}\text { Mus muscu- } \\
\text { lus }\end{array}$ & $\mathrm{M}$ & 0.83 & $\mathrm{PF} / \mathrm{DF}$ & C57BL/6J & WT & 1 & ND & NA \\
\hline 11 & $\begin{array}{c}\text { Mus muscu- } \\
\text { lus }\end{array}$ & M & 0.83 & $\mathrm{PF} / \mathrm{DF}$ & C57BL/6J & WT & 1 & ND & NA \\
\hline 12 & $\begin{array}{c}\text { Mus muscu- } \\
\text { lus }\end{array}$ & $\mathrm{F}$ & 0.66 & $\mathrm{PF} / \mathrm{DF}$ & C57BL/6J & $\begin{array}{c}\alpha \text {-syn } \\
\text { KO }\end{array}$ & 0 & 1 & NA \\
\hline 13 & $\begin{array}{c}\text { Mus muscu- } \\
\text { lus }\end{array}$ & $\mathrm{F}$ & 0.66 & $\mathrm{PF} / \mathrm{DF}$ & C57BL/6J & $\begin{array}{c}\alpha \text {-syn } \\
\text { KO }\end{array}$ & 0 & 1 & NA \\
\hline 14 & $\begin{array}{c}\text { Mus muscu- } \\
\text { lus }\end{array}$ & $\mathrm{F}$ & 0.66 & $\mathrm{PF} / \mathrm{DF}$ & C57BL/6J & $\begin{array}{c}\alpha \text {-syn } \\
\text { KO }\end{array}$ & 0 & 1 & NA \\
\hline 15 & $\begin{array}{c}\text { Mus muscu- } \\
\text { lus }\end{array}$ & $\mathrm{F}$ & 0.66 & $\mathrm{PF} / \mathrm{DF}$ & C57BL/6J & WT & 1 & 1 & NA \\
\hline 16 & $\begin{array}{c}\text { Mus muscu- } \\
\text { lus }\end{array}$ & $\mathrm{F}$ & 0.66 & $\mathrm{PF} / \mathrm{DF}$ & C57BL/6J & WT & 1 & 1 & NA \\
\hline 17 & $\begin{array}{c}\text { Mus muscu- } \\
\text { lus }\end{array}$ & $\mathrm{F}$ & 0.66 & $\mathrm{PF} / \mathrm{DF}$ & C57BL/6J & WT & 1 & 1 & NA \\
\hline 18 & $\begin{array}{c}\text { Mus muscu- } \\
\text { lus }\end{array}$ & $\mathrm{F}$ & 0.66 & $\mathrm{PF} / \mathrm{DF}$ & C57BL/6J & WT & 1 & 1 & NA \\
\hline 19 & $\begin{array}{c}\text { Mus muscu- } \\
\text { lus }\end{array}$ & $\mathrm{F}$ & 0.66 & $\mathrm{PF} / \mathrm{DF}$ & C57BL/6J & WT & 1 & 1 & NA \\
\hline
\end{tabular}


bioRxiv preprint doi: https://doi.org/10.1101/2021.12.22.473905; this version posted January 12,2022 . The copyright holder for this preprint (which was not certified by peer review) is the author/funder, who has granted bioRxiv a license to display the preprint in perpetuity. It is made available under aCC-BY-NC-ND 4.0 International license.

Distribution of Phosphorylated Alpha-synuclein

\begin{tabular}{|c|c|c|c|c|c|c|c|c|c|}
\hline 20 & $\begin{array}{c}\text { Mus muscu- } \\
\text { lus }\end{array}$ & $\mathrm{F}$ & 0.83 & $\mathrm{PF} / \mathrm{DF}$ & $\mathrm{C} 57 \mathrm{BL} / 6 \mathrm{~J}$ & WT & 1 & ND & NA \\
\hline 21 & $\begin{array}{c}\text { Mus muscu- } \\
\text { lus }\end{array}$ & F & 0.83 & $\mathrm{PF} / \mathrm{DF}$ & $\mathrm{C} 57 \mathrm{BL} / 6 \mathrm{~J}$ & WT & 1 & ND & NA \\
\hline 22 & $\begin{array}{c}\text { Rattus } \\
\text { norvegicus } \\
\text { domestica }\end{array}$ & NA & 1.33 & DF & SD & WT & 0 & 1 & NA \\
\hline 23 & $\begin{array}{c}\text { Rattus } \\
\text { norvegicus } \\
\text { domestica }\end{array}$ & NA & 1.33 & DF & SD & WT & 1 & 1 & NA \\
\hline 24 & $\begin{array}{c}\text { Rattus } \\
\text { norvegicus } \\
\text { domestica }\end{array}$ & NA & 1.33 & DF & SD & WT & 1 & 1 & NA \\
\hline$\$ 25$ & $\begin{array}{c}\text { Macaca fas- } \\
\text { cicularis }\end{array}$ & M & 10.86 & $\mathrm{PF} / \mathrm{DF}$ & NA & WT & 1 & 1 & NA \\
\hline 26 & $\begin{array}{c}\text { Macaca fas- } \\
\text { cicularis }\end{array}$ & $\mathrm{F}$ & 5.59 & $\mathrm{PF} / \mathrm{DF}$ & NA & WT & 1 & 1 & NA \\
\hline 27 & $\begin{array}{l}\text { Homo sapi- } \\
\quad \text { ens }\end{array}$ & M & 93.24 & $\mathrm{DF}$ & NA & NA & 0 & 0 & NS \\
\hline 28 & $\begin{array}{l}\text { Homo sapi- } \\
\quad \text { ens }\end{array}$ & M & 87.8 & DF & NA & NA & 0 & ND & NS \\
\hline 29 & $\begin{array}{l}\text { Homo sapi- } \\
\quad \text { ens }\end{array}$ & $\mathrm{F}$ & 74.1 & $\mathrm{DF}$ & NA & NA & 0 & 0 & NS \\
\hline 30 & $\begin{array}{l}\text { Homo sapi- } \\
\quad \text { ens }\end{array}$ & $\mathrm{F}$ & 87 & DF-Paraffin & NA & NA & 1 & 1 & NS \\
\hline 31 & $\begin{array}{l}\text { Homo sapi- } \\
\quad \text { ens }\end{array}$ & NK & NK & DF & NA & NA & 0 & 0 & PD/DLB \\
\hline 32 & $\begin{array}{l}\text { Homo sapi- } \\
\quad \text { ens }\end{array}$ & NK & NK & DF & NA & NA & 0 & 0 & PD/DLB \\
\hline 33 & $\begin{array}{l}\text { Homo sapi- } \\
\quad \text { ens }\end{array}$ & NK & NK & DF & NA & NA & 0 & 0 & $\mathrm{PD} / \mathrm{DLB}$ \\
\hline 34 & $\begin{array}{l}\text { Homo sapi- } \\
\quad \text { ens }\end{array}$ & NK & NK & DF & NA & NA & 0 & 0 & PD/DLB \\
\hline 35 & $\begin{array}{l}\text { Homo sapi- } \\
\quad \text { ens }\end{array}$ & NK & NK & DF & NA & NA & 0 & 0 & $\mathrm{PD} / \mathrm{DLB}$ \\
\hline$\S 36$ & $\begin{array}{l}\text { Homo sapi- } \\
\quad \text { ens }\end{array}$ & NK & NK & DF & NA & NA & 1 & 1 & $\mathrm{PD} / \mathrm{DLB}$ \\
\hline
\end{tabular}

Notes. * EP1536Y was used to stain mitral cell PSER129. †TBX21 is a mitral cell marker. 0 means no staining and 1 means staining. $\ddagger$ For specimen 25 , animal was euthanized due to post op-right subdural hematoma. §Specimen 36 had weak TBX-21 staining but was observed in the citrate retrieval condition. DF = Drop-fixation, $\mathrm{PF}=\mathrm{Perfusion}$ fixation, DF-Paraffin $=$ Drop-fixation followed by paraffin embedding. NS $=$ non-synucleinopathy. $\mathrm{PD} / \mathrm{DLB}=$ Clinical Parkinson's disease or Dementia with Lewy bodies, postmortem conformation by pathology. NK = not known. 
bioRxiv preprint doi: $\mathrm{https}$ ://doi.org/10.1101/2021.12.22.473905; this version posted January 12, 2022. The copyright holder for this preprint (which was not certified by peer review) is the author/funder, who has granted bioRxiv a license to display the preprint in perpetuity. It is made available under aCC-BY-NC-ND 4.0 International license.

\section{Distribution of Phosphorylated Alpha-synuclein}

A
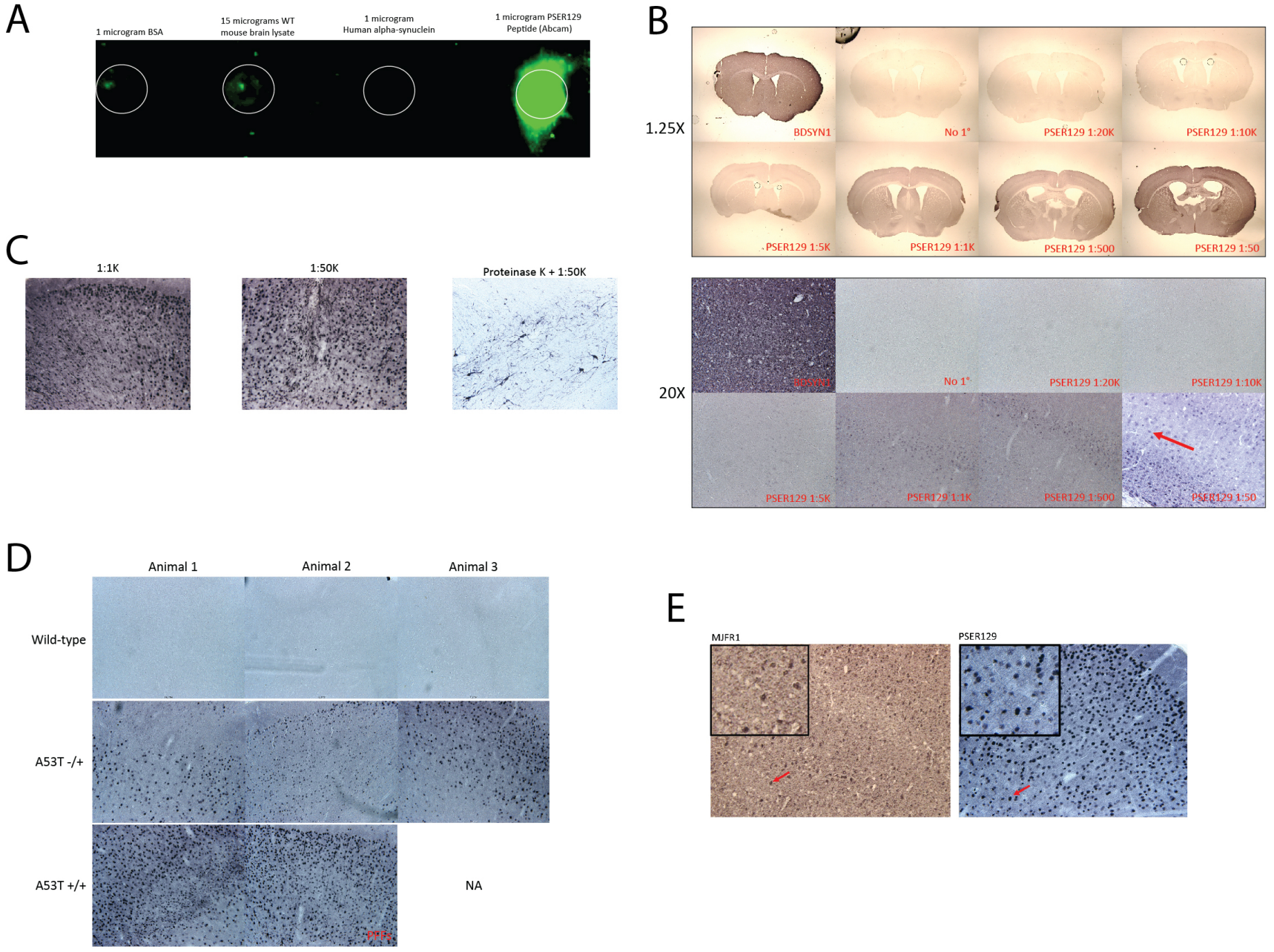

E

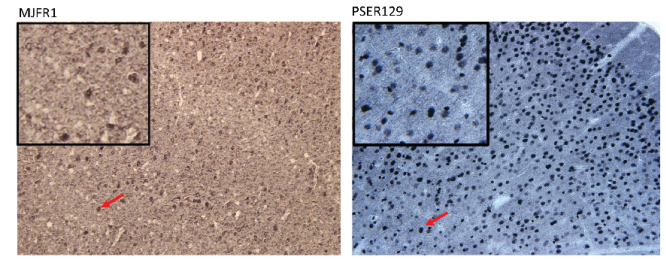

$\mathrm{F}$

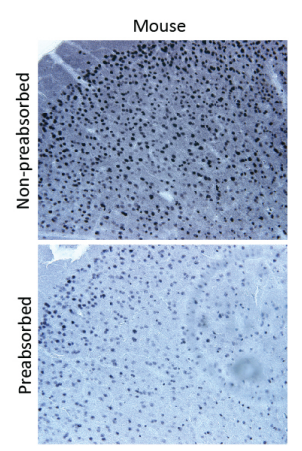

Mouse 2
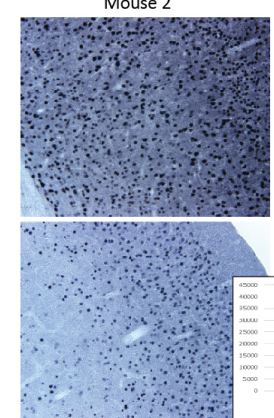

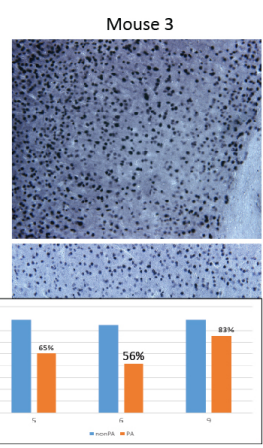

G

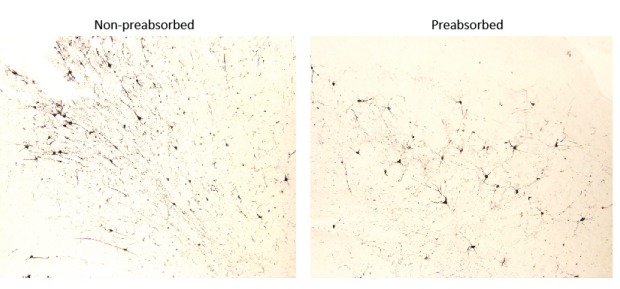

Figure S1: Validation Experiments in M83 mice and WT mice. (A) Dot-blot demonstrates EP1536Y reactivity against several samples of interest. (B) EP1536Y dilution experiments. Brain sections from wild-type mice were probed with the antibody BDSYN1 (total synuclein) or several dilutions of EP1536Y and developed with DAB or nickel enhanced DAB. Low and high magnification images of the resulting reactivity. Higher dilutions were required to avoid perfuse reactivity in the brain. (D) PSER129 reactivity in WT and A53T alpha-synuclein overexpressing mice (M83). At high dilutions, PSER129 reactivity was seen throughout the M83 brain. (E) Antibody MJFR1 only reacts to human alpha-synuclein. M83 mice show similar tissue distribution of human alpha-synuclein as PSER129 tissues distribution. This suggests that expressed human alpha-synuclein is phosphorylated. (F) Preabsorption of EP1536Y antibody. The antibody was preaborbed against excesses alpha-synuclein phosphopeptide (abcam). The preabsorbed antibody was then used to stain brain sections from M83 mice not baring alpha-synuclein pathology. Results show a reduction in signal, but not a loss of staining, typical of monoclonal antibody reactivity. (G) Preabsorbed antibody was used to stain proteinase K treated M83 mouse brains baring alpha-synuclein pathology. Similarly, pathology detection was inhibited with preabsorbtion, but not eliminated. 
bioRxiv preprint doi: https://doi.org/10.1101/2021.12.22.473905 this version posted January 12, 2022. The copyright holder for this preprint (which was not certified by peer review) is the author/funder, who has granted bioRxiv a license to display the preprint in perpetuity. It is made available under aCC-BY-NC-ND 4.0 International license.

Distribution of Phosphorylated Alpha-synuclein

\section{Non-human Primate}
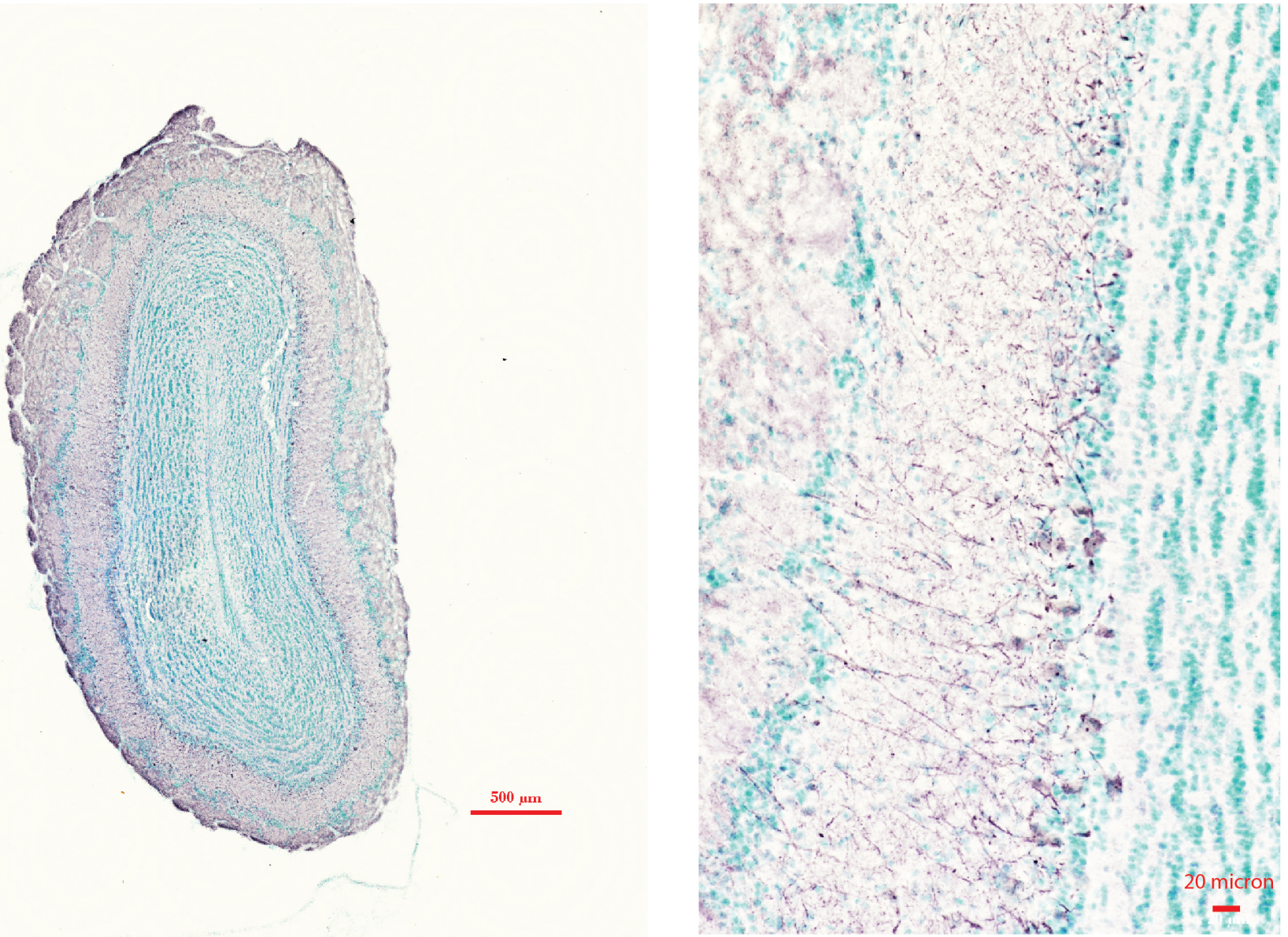

Figure S2: Antibody pSyn\#64 reactivity in OB of a healthy non-human primate. Formalin fixed floating coronal sections from a cynomolgus monkey were incubated with mouse monoclonal antibody pSyn\#64 (FuJIFILM Wako Pure Chemical Corporation) and detected using tyramine signal amplification. Sections were counterstained with methyl green. The left image depicts a whole section scan, and the left image depicts an image taken with a $20 \mathrm{X}$ objective. Scale bars are depicted on each image. 
bioRxiv preprint doi: https://doi.org/10.1101/2021.12.22.473905- this version posted January 12, 2022. The copyright holder for this preprint (which was not certified by peer review) is the author/funder, who has granted bioRxiv a license to display the preprint in perpetuity. It is made available under aCC-BY-NC-ND 4.0 International license.

Distribution of Phosphorylated Alpha-synuclein

A

B

\section{No Treatment HIAR}
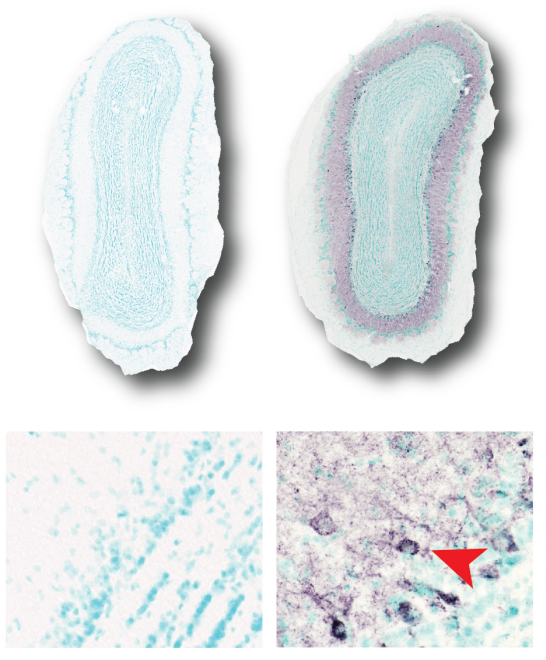

PK
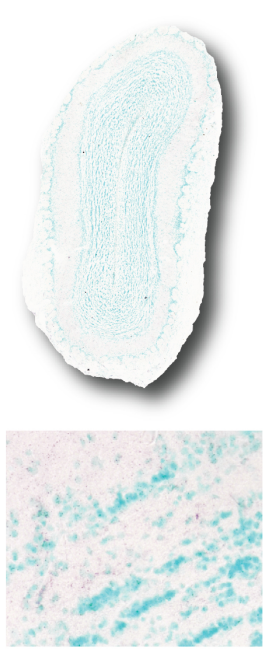

No Treatment

HIAR

PK

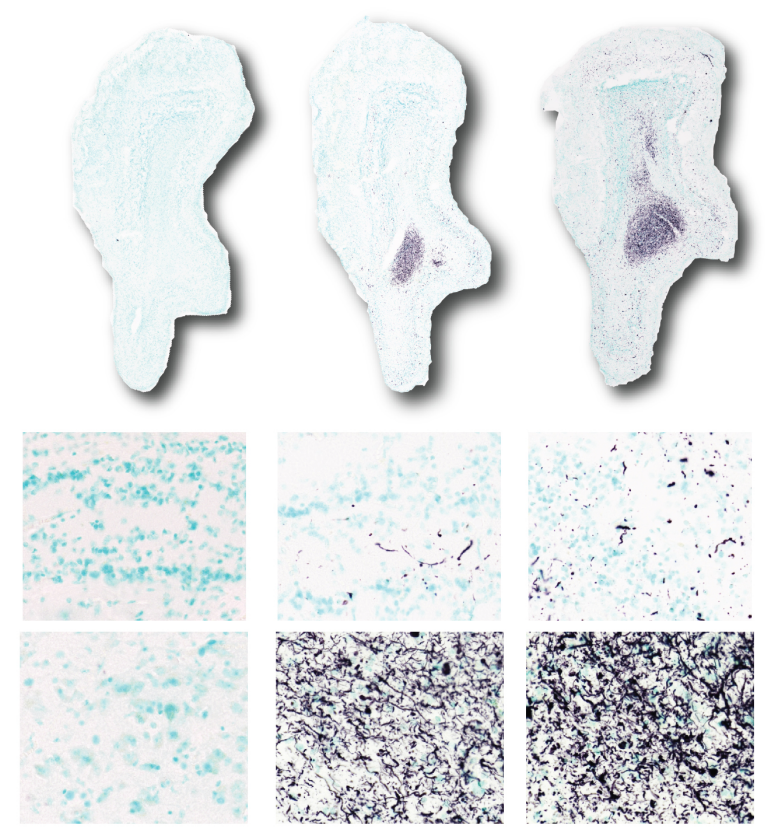

Figure S3: Detection of PSER129 is dependent on antigen retrieval techniques. Olfactory bulb sections from a non-human primate (A) and individual with PD (B) were immunostained using the EP1536Y antibody under different tissue processing conditions. For the "no treatment" condition tissues were stained as floating sections without antigen retrieval. For "HIAR" tissues were mounted onto slides and heated to $\sim 95^{\circ} \mathrm{C}$ in citrate buffer for $30 \mathrm{~min}$. For "PK" samples were mounted onto slides and treated with $20 \mu \mathrm{g} / \mathrm{mL}$ proteinase K for $10 \mathrm{~min}$ at $37^{\circ} \mathrm{C}$. Resulting EP1536Y immunoreactivity for each condition is depicted. Red arrow highlights PSER129 reactivity in mitral cells. 
bioRxiv preprint doi: https://doi org/10.1101/2021.12.22.473905- this version posted January 12, 2022. The copyright holder for this preprint (which was not certified by peer review) is the author/funder, who has granted bioRxiv a license to display the preprint in perpetuity. It is made available under aCC-BY-NC-ND 4.0 International license.

Distribution of Phosphorylated Alpha-synuclein
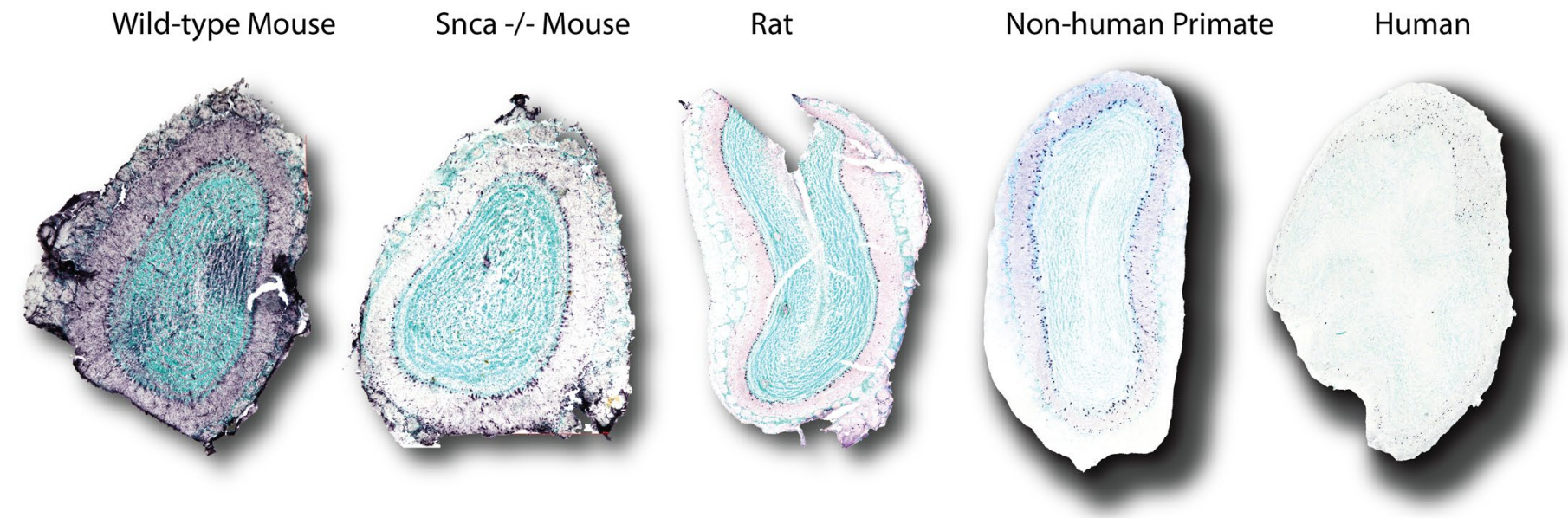

Figure S4: TBX21 reactivity in the OB. Immunoreactivity of mitral cell marker TBX21 in OB specimens from each species assessed in this study. TBX21 reactivity was observed in the mitral cell layer across species. High background was observed in the mouse specimens because the anti-TBX21 antibody was of mouse origin. 